\title{
CRITICAL SUCCESS FACTORS FOR BUILDING INFORMATION MODELLING (BIM) IMPLEMENTATION FOR POWER PLANT PROJECTS IN MALAYSIA
}

\author{
Mohd Azrul Aziz ${ }^{1}$, Chee Fui Wong ${ }^{2 *}$, Nuzul Azam Haron ${ }^{3}$, \\ Aidi Hizami Ales ${ }^{3}$, RaJa AhMAd AZMeER RaJa Ahmad EFFendi ${ }^{4}$ \\ AND OOI KUAN TAN ${ }^{2}$ \\ ${ }^{I} T N B$ Power Generation Sdn Bhd, PJX HM Shah Tower, Jalan Persiaran Barat, \\ 46500, Petaling Jaya, Selangor, Malaysia \\ ${ }^{2}$ Department of Civil Engineering, Lee Kong Chien Faculty of Engineering and Science, \\ Universiti Tunku Abdul Rahman, 43000, Kajang, Selangor, Malaysia \\ ${ }^{3}$ Department of Civil Engineering, Faculty of Engineering, Universiti Putra Malaysia, \\ 43400, Seri Kembangan, Selangor, Malaysia; \\ ${ }^{4}$ Department of Industrial Design, Faculty of Design and Architectural, \\ Universiti Putra Malaysia, 43400, Seri Kembangan, Selangor, Malaysia \\ *Corresponding author: cfwong@utar.edu.my
}

(Received: 22 $2^{\text {nd }}$ June 2021; Accepted: $17^{\text {th }}$ October 2021; Published on-line: $4^{\text {th } J a n u a r y ~ 2022) ~}$

\begin{abstract}
Building Information Modelling (BIM) has become increasingly important for the construction industry in Malaysia. BIM implementation process requires proper strategic planning and considerations from many aspects.Malaysian government has realised the importance of BIM as an emerging technology to transform the construction industry in Malaysia, and thus has classified BIM as one of the twelve main technology in CIDB “Construction 4.0 Strategic Plan 2021-2025”. BIM implementation offer significant benefits to the power generation sector in Malaysia Thisstudy was conducted using the quantitaive research method in which questionnaires survey were distributed to the clients ${ }^{\text {}}$ representatives in the Malaysian power sector. This study has identified the 13 critical success factors to be considered by clients for BIM implementation in power plant projects in Malaysia. The success factors were classified based on the four (4) main fields or factors namely management, people, process and technology. The study findings show that management support is the most important success factor for the power plant projects while other success factors such as people, process and technology were also identified and discussed.
\end{abstract}

ABSTRAK: Model Pembangunan Maklumat (BIM) merupakan sebuah konsep penting bagi industri pembinaan di Malaysia. Proses pelaksanaan BIM memerlukan perancangan strategik dan pertimbangan wajar dari pelbagai aspek. Kerajaan Malaysia sedar akan kepentingan BIM sebagai teknologi pemangkin dalam transformasi industri pembinaan Malaysia di mana BIM telah disenaraikan sebagai salah satu daripada 12 teknologi utama dalam CIDB "Plan Strategik 4.0 Pembangunan 2021-2025". Pelaksanaan BIM memberi faedah ketara kepada sektor jana kuasa di Malaysia. Kajian ini dibuat menggunakan kaedah kuantitatif melalui kaji selidik ke atas wakil klien dalam sektor tenaga Malaysia. Kajian ini telah mengenal pasti 13 faktor kejayaan kritikal yang perlu dipertimbangkan oleh klien bagi menghasilkan projek loji jana kuasa di Malaysia. Faktor kejayan ini telah diklasifikasi berdasarkan 4 bidang utama seperti pengurusan, pekerja, proses dan teknologi. Dapatan kajian menunjukkan bahawa sokongan daripada pihak pengurusan 
merupakan faktor utama bagi kejayaan sesebuah projek jana kuasa, di samping faktorfaktor lain seperti pekerja, proses dan teknologi juga telah dikenal pasti dan dibincangkan.

\section{KEYWORDS: building information modelling (BIM); power plant project; BIM implementation}

\section{INTRODUCTION}

The construction industry is a vital part of the economy, environment, and society. The construction activities affect the quality of human life. Other industries especially the economic related industries are connected to the construction industry since all industries require buildings or other built assets. In Malaysia, construction industry contributed almost 5\% to the national Gross Domestic Product (GDP) and 9\% to employment in 2016, with more than 100 other industries depended on construction for their growth [1]. Based on recent report produced by Bank Negara Malaysia [2], the construction sector registered slightly higher growth at $0.5 \%$ for the second (2nd) quarter of the year 2019 which contributed mainly by residential and special trade sub-sectors to become $4.9 \%$ of the national GDP. As reported by World Economic Forum 2016 [3], the construction industry is the largest raw material consumer globally with $50 \%$ of steel production and more than three billion tons of raw materials. The industry contributes $6 \%$ of total global GDP. Therefore, any improvement in productivity as well as successful adoption of modern innovative will contribute major impact to the industry.

Electric energy produced by the power plants is very essential for economic growth and development of any country. Among the major power plants standings on the globe are and the hydroelectric power plants and the thermal power plants which converts heat intro electric energy such as the conventional steam power plant, diesel power plant, gas turbine power plant, and nuclear power plant [4]. Another source for electric energy comes from renewable energy which naturally reloaded by nature such as solar, wind, small hydropower, biomass, geothermal and tidal energy [5]. According to the BP Statistical Review of World Energy (2019) [6], energy consumption grew at a rate of $2.9 \%$ in 2018, almost double its 10 -year average of $1.5 \%$ per year, and the fastest since 2010 .

In relation to IR 4.0 and innovation, power plants that approach innovative digitalization strategy will gain significant competitive advantage as well as sustaining operational efficiency throughout the plant's lifecycle [7]. In this perspective, Building Information Modelling (BIM) is specified as the key platform of digital technology to be adopted. Based on the evaluation and estimation from industry experts on the case study of BIM application at a gas turbine power plant; potential cost saving in design, engineering and construction is estimated at $10 \%$ to $20 \%$, while in operation phase is estimated at $8 \%$ to $13 \%$ [8].

Building Information Modelling (BIM) is the key enabler for technology innovations in the construction industry. By adopting BIM, project's lifecycle costs can be reduced by almost $20 \%$ and BIM can significantly improve completion time, quality, and safety [9]. Instead of recording information in drawings, as conventional practice by the industry players, BIM stores, maintains and exchanges information through comprehensive digital representations in the building information models. This methodology intensely improves the coordination of the design activities, the integration of simulations, the setup and control of the construction process, as well as the handover of building information for the operator or end user. Furthermore, by reducing the manual data entry, difficulty and error-prone work can be avoided, thus increase the productivity and quality of the construction projects [10]. 
BIM as part of ICT was recognized as vital in improving the construction industry in Malaysia. However, the implementation process requires proper strategic planning and considerations from many aspects [11]. Beside construction sector, BIM implementation can benefit the power generation sector in Malaysia. However, since there is no report and research related to the BIM adoption in the power plant projects in Malaysia, it is anticipated that BIM was only applied during design and construction stage by the international contractors or consultants and does not benefit the local clients throughout the projects' lifecycle. Therefore, it is crucial to identify the current level of BIM implementation in power plant projects in Malaysia, the benefits that BIM can offer to projects' stakeholders especially the clients, and the success factors to be considered by the clients,

This research focused on the clients' perspective of Malaysian conventional power plants which comprise the coal-fired power plants, gas turbine power plants, co-generation power plants, and hydroelectric power plants. Additionally, the assessed power plant projects were constructed between year 2010 to 2019 throughout Peninsular Malaysia, Sabah and Sarawak, when BIM implementation was relevant. This research is primarily interested in assessing the benefits that BIM can offer throughout the lifecycle the power plant projects and factors to be considered for successful BIM implementation in power plant projects in Malaysia.

\section{BUILDING INFORMATION MODELLING FOR POWER PLANT PROJECTS IN MALAYSIA}

\subsection{Power Plants in Malaysia}

Based on data retrieved from Malaysian Energy Commission in 2017, there were 61 existing power plants excluding 13 new power plant projects that were under construction or negotiation throughout Malaysia $[12,13]$. This 2017 research only concentrated on the clients' perspective of Malaysian conventional power plants which comprise coal-fired power plants, gas turbine power plants, and hydroelectric power plants. The research excludes renewable energy power plants such as solar and wind power plants. Therefore, focus then given to conventional power plant projects that has been constructed between year 2014 to 2025 in Peninsular Malaysia, Sabah, and Sarawak, as BIM implementation is relevant throughout that duration. As shown in Table 1 there are 23 projects that were completed, or still ongoing construction, or in negotiation phase within that duration.

\subsection{BIM Implementation in the Construction of Electrical Power Plants}

There are two types of power plants in Malaysia which are thermal power plants and hydroelectric plants. Thermal power plants generate electricity from coal, natural gas, biomass and fuel oil, while hydropower plants transform water-heads into electric energy through water turbine [14]. According to survey by Royal Institute of Chartered Surveyor in 2013 [15], BIM is suitable for larger and more complex buildings such as power plant, thus benefited in term of design consistency and visualization, cost estimations, clash detection, implementation of lean construction or improved stakeholder collaboration. Basically, BIM model is created by incorporating structures, equipment, instruments, piping and electrical facilities mainly for space management by the designers or contractors [16]. Boston Consulting Group in 2016, reported that based on case study of BIM application at a gas turbine power plant; potential cost saving in design, engineering and construction is estimated at $10 \%$ to $20 \%$ while in operation phase is estimated at $8 \%$ to $13 \%$ [17]. 
Table 1: List of power plant projects in Malaysia from 2014 until 2025 [18].

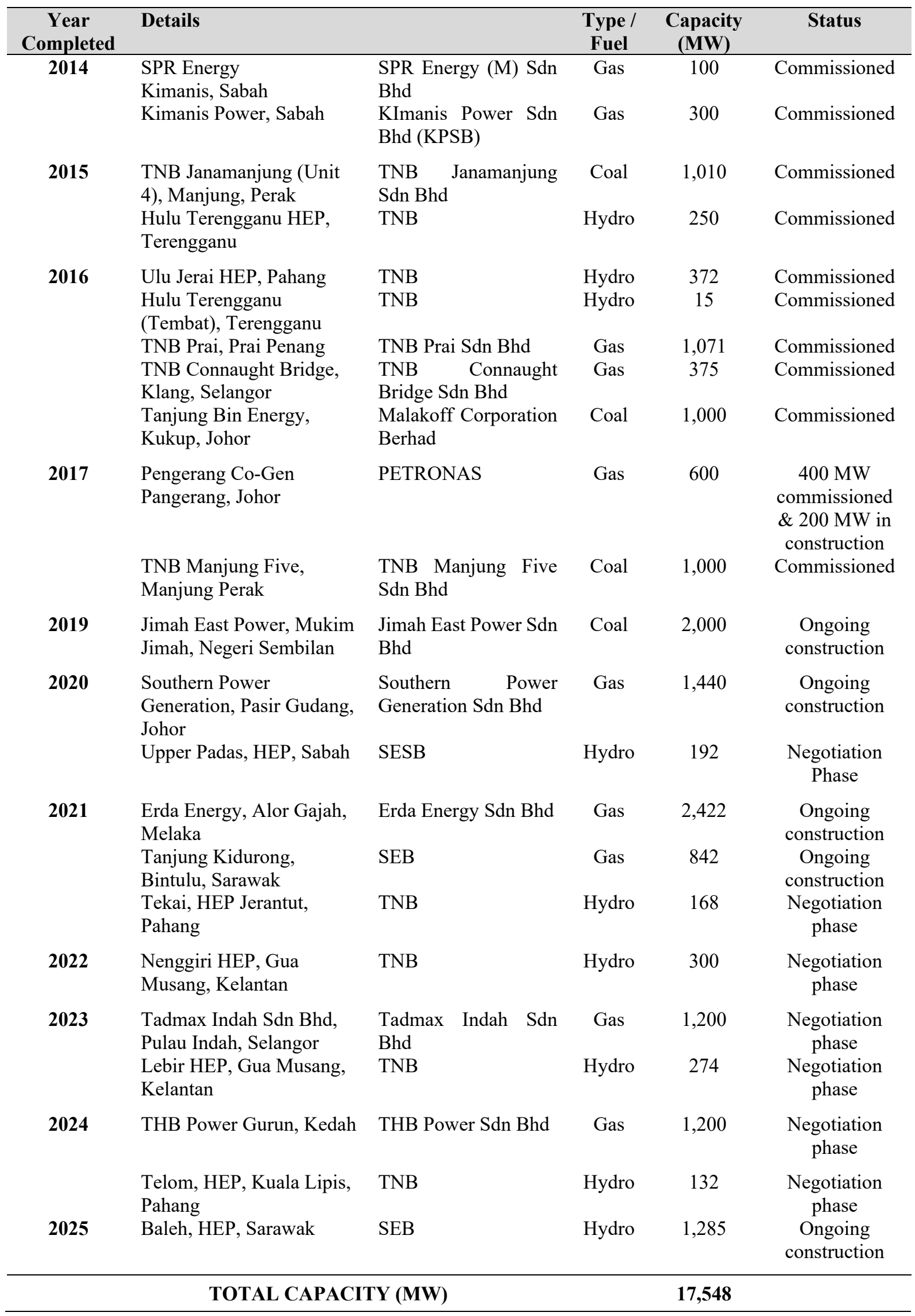


Compared to normal building projects which usually use Autodesk Revit and Autodesk Naviswork for BIM modelling, power plant projects require special BIM software for power plant design and modelling. Among the popular software in market for the plant design is E3D (Aveva), PDS and Smart3D (Intergraph), Bentley Plant Wise and Autodesk Plant 3D. According to Gerber \& Rice (2010), [16] the hydro powerplant project "Hunan Hydro \& Power Design Institute" which was developed by Hanjiang Yakou Shipping Hub was selected as the winner for the 'Going Digital Advancements in Power Generation' category in year 2019. The BIM model for this project was developed using Bentley's Open Buildings Designer software that helped complete design works within 45 days and helped collaborative environment to eliminate errors and material shortages, thus reduced on-site change orders by $80 \%$. Overall, the Bentley software helped the team to complete the task three months ahead of work schedule [19].

In Malaysia, Construction Industry Development Board (CIDB) has defined BIM as modelling technology and associated set of processes to produce, communicate, analyse and use as digital information models throughout the construction project life cycle. BIM is an intelligent three-dimension (3D) model-based process that gives the architecture, engineering, and construction professionals an insight and tools to plan more efficiently, design, construct and manage buildings and infrastructure [20].

Malaysian government has realised the importance of BIM as an emerging technology to transform the construction industry in Malaysia where BIM has been classified as one of the twelve main technologies in CIDB "Construction 4.0 Strategic Plan 2021-2025". The Construction Industry Transformation Programme 2016 -2020 (CITP 2016-2020) was introduced to transform the Malaysian construction industry into one that is highly productive, sustainable and world-class by 2020 . Under CIDB productivity strategic thrust, a key initiative is to roll out technological advantage across project life cycle by using advanced technologies such as BIM. The CITP 2016-2020 has outlined BIM as an emerging technology that will improve the construction productivity. The Ministry of Works of Malaysia through the Public Works Department 's (JKR) Strategic Plan 2021-2025 has set the adoption of the mechanism to reach $50 \%$ by 2021 and $80 \%$ by 2025 [21].

The benefits that the power plant clients from the Malaysian industry perspective during planning and design stages can gain from BIM implementation are better understanding via model visualization in 3D, quicker approvals of project at early stages, upfront involvement of key stakeholders for earlier feedback, intelligent transfer of information between stakeholders, and improved efficiency for design production. Meanwhile, during construction stage, the benefits would be improved coordination between client-consultantcontractor, improved communication between all stakeholders, reduce construction errors and waste, effective and accurate project time planning and sequencing, produce accurate quantity and cost estimate, and improved safety, quality and risk identification.

\section{RESEARCH METHOD}

\subsection{Project Sampling and Research Method}

This research is conducted using quantitative methods with questionnaire survey distributed amongst the clients' representatives in Malaysian power sector. The clients' engineers or technical representatives of the identified power plant projects were to answer closed ended questions in order to gain a thorough understanding on the BIM implementation over Malaysian power plant projects. 
The respondents for this quantitative study are the four personnel that are involved in the BIM implementation of twenty-three (23) projects, namely BIM coordinator, civil engineer, mechanical engineer, and electrical or control \& instrumentation (C\&I) engineer. Therefore, by multiplying with 23 projects, the total number of respondents, the client's representative for BIM implementation in the Malaysian power plant projects perspective, is 92 . Subsequently by referring to formula as indicated below [22], a sample size of 42 was obtained at $90 \%$ confidence level which gives score, $\mathrm{Z}$ of 1.65 ; sample proportion of $50 \%$; and margin error of $10 \%$.

$$
n=N \times \frac{\frac{Z^{2} \times p(1-p)}{e^{2}}}{\left[N-1+\left(\frac{Z^{2} \times p(1-p)}{e^{2} N}\right)\right]}=92 \times \frac{\frac{1.65^{2} \times 0.5(1-0.5)}{0.1^{2}}}{\left[92-1+\left(\frac{1.65^{2} \times 0.5(1-0.5)}{0.1^{2} \times 92}\right)\right]}=40
$$

where;

$\mathrm{N}=$ Population size,

$\mathrm{Z}=$ Critical value of the normal distribution at the required confidence level,

$\mathrm{p}=$ Sample proportion,

$\mathrm{e}=$ Margin of error

The study by Roscoe [23], indicated that the appropriate sample size for a study must be ranged between 30 to 500 . More than 30 respondents were deemed as the best population for sampling in this study context and followed the rules of thumb in determining the sample size [23] [24]. Therefore, the sample size of 42 has met the requirement of sampling design and 1was adopted for the purpose of this study.

Questionnaire data were collected using various methods such as personal questionnaire, mail questionnaires, and electronic questionnaires. This method made the questionnaire easily accessible and made compiling data effortless [25]. The questions were generated from the literature review and distributed to the relevant personnel using online platforms such as email, WhatsApp and LinkedIn. The four sections of the structured questionnaire consist of the respondent's details, respondent's background, benefits of BIM, and success factors for BIM implementation using content-based and close-ended questions. The questionnaire used was checked for validity and reliability before distribution. The quantitative data was then coded and analysed using descriptive statistics such as percentages and mean and standard deviation. Statistical Package for Social Sciences (SPSS version 23.0) were employed to aid in the coding, entry and analysis of the data obtained through questionnaires.

The reliability analysis using Cronbach's alpha coefficient was conducted in this study to examine the validity of the data on the benefits of BIM to clients and the Pareto analysis was used to determine the critical success factors for BIM implementation for power plants projects in Malaysia. According to [26], reliability analysis refers to the stability and consistency of items in the study. Additionally [27], stated that reliability is the extent to which results are consistent over time and representative of the total population of the study. In this study the reliability of all variables was examined by Cronbach's alpha score.

The Pareto analysis which was founded by Vilfredo Pareto in the late 1940s was adopted fort his research. Pareto analysis is a formal technique useful with many possible courses of action are competing for attention. In essence, the problem-solver estimates the benefit delivered 115 by each action while it is common to refer to Pareto as "80/20" rule under the assumption that in all situations, $20 \%$ of cause determine $80 \%$ of problems. 


\section{RESULTS AND DISCUSSION}

\subsection{Research Respondents}

The aim of this research was to examine the benefits of Building Information Modelling (BIM) to power plant projects' clients throughout the project lifecycle and to determine the critical success factors for BIM implementation of power plants projects in Malaysia.

This research collected 42 questionnaires responses from the conventional power plant projects stakeholders that include the Tenaga National Berhad (TNB), Sarawak Energy Berhad (SEB), Southern Power Generation (SPG), Sabah Electricity Sdn Bhd (SESB), TNB Prai Sdn Bhd, TNB Manjung Five Sdn Bhd, Jimah East Power Sdn Bhd (JEP), Petronas, Kimanis Power Sdn Bhd (KPSB), TNB Janamanjung Sdn. Bhd. and TNB Connaught Bridge $\mathrm{Sdn}$. Bhd. Table 2 summarises the respondents' organisation. The respondents 'designation and years of service in the organisation were tabulated in Table 3 and Table 4 . Table 5 shows the summary of the involvement of the respondents in power plant projects. The result indicates that majority of the respondents were involved in one or two power plant projects, $40.5 \%$ or 17 respondents were involved in only one project, $42.9 \%$ or 18 respondents were already involved in two power plant projects. Additionally, five respondents (11.9\%) were involved in three projects, and only two respondents (4.8\%) were involved in all four types of power plant projects which are covered in this study, namely gas fired power plant, coalfired power plant, co-generation power plant and hydroelectric power plant.

Table 2: Respondent's organisation

\begin{tabular}{lcc}
\hline \multicolumn{1}{c}{ Name of Organisation } & n & \% \\
\hline Tenaga Nasional Berhad & 22 & 52.4 \\
Sarawak Energy Berhad & 4 & 9.5 \\
Southern Power Generation & 3 & 7.1 \\
Sabah Electricity Sdn Bhd & 2 & 4.8 \\
TNB Prai Sdn Bhd & 2 & 4.8 \\
TNB Manjung Five Sdn Bhd & 2 & 4.8 \\
Jimah East Power Sdn Bhd & 2 & 4.8 \\
Petronas & 2 & 4.8 \\
Kimanis Power Sdn Bhd & 1 & 2.4 \\
TNB Janamanjung Sdn. Bhd. & 1 & 2.4 \\
TNB Connaught Bridge Sdn Bhd & 1 & 2.4 \\
\hline \multicolumn{1}{c}{ TOTAL } & $\mathbf{4 2}$ & $\mathbf{1 0 0}$ \\
\hline
\end{tabular}

Table 3: Respondent's designation

\begin{tabular}{lcc}
\hline \multicolumn{1}{c}{ Designation } & $\mathrm{n}$ & $\%$ \\
\hline Engineer & 16 & 38.1 \\
Senior Engineer & 15 & 35.7 \\
Manager & 5 & 11.9 \\
Executive & 4 & 9.5 \\
Senior Manager & 2 & 4.8 \\
\hline \multicolumn{1}{r}{ TOTAL } & 42 & 100 \\
\hline
\end{tabular}


Table 4: Respondent's year of organisation

\begin{tabular}{|c|c|c|}
\hline Years in Organisation & $\mathrm{n}$ & $\%$ \\
\hline $1-5$ years & 13 & 31.0 \\
\hline $6-10$ years & 13 & 31.0 \\
\hline $11-15$ years & 12 & 28.6 \\
\hline $16-20$ years & 2 & 4.8 \\
\hline More than 20 years & 2 & 4.8 \\
\hline TOTAL & 42 & 100 \\
\hline
\end{tabular}

Table 5: Respondent's involvement in power plant project

\begin{tabular}{lcc}
\hline \multicolumn{1}{c}{ Involvement of Power Plant Project } & $\mathrm{n}$ & $\%$ \\
\hline 1 Type of Power Plant Project Only & 17 & 40.5 \\
2 Type of Power Plant Projects & 18 & 42.9 \\
3 Type of Power Plant Projects & 5 & 11.9 \\
All 4 Type of Power Plant Projects & 2 & 4.8 \\
\hline \multicolumn{1}{c}{ TOTAL } & 42 & 100 \\
\hline
\end{tabular}

\subsection{Reliability Analysis}

Table 6 indicates the reliability analysis of critical success factors for BIM implementation along the lifecycle of power plants projects in Malaysia. The value of Cronbach's alpha for management, people, process and technology were recorded at 0.946 , $0.893,0.914$ and 0.948 respectively. All items of the reliability analysis were considered acceptable since the value is greater than 0.60 [24].

Table 6: Reliability analysis for critical success factors for BIM implementation throughout the lifecycle of power plants projects in Malaysia

\begin{tabular}{cc}
\hline Variables & Cronbach's alpha \\
\hline Management & 0.946 \\
People & 0.893 \\
Process & 0.914 \\
Technology & 0.948 \\
\hline
\end{tabular}

\subsection{Benefits of BIM Implementation}

BIM practices have been very beneficial in achieving project success. The finding for this quantitative study was formulated using Likert Scale approach and the respondents were asked to rate what their opinion on the listed BIM benefits based on their knowledge or experience in applying BIM in their power plant projects. These responses were assessed through ranking based on Average Index (Ai) values presented in Table 7.

\subsection{Critical Success Factors for BIM Implementation}

The critical success factors for BIM implementation were assessed through the questionnaires using Likert Scale approach. The respondent's opinion on the listed critical success factors for BIM implementation based on their knowledge or experience in applying BIM in their power plants projects were assess and ranked using the Average Index (AI) values and presented in Table 8. 
Table 7: Benefits of BIM Implementation (Overall)

\begin{tabular}{|c|c|c|c|c|}
\hline No & Benefits of BIM & AI & $\begin{array}{l}\text { Standard } \\
\text { Deviation }\end{array}$ & Rank \\
\hline 1. & $\begin{array}{l}\text { Construction Stage- Improved coordination between } \\
\text { client-consultant-contractor }\end{array}$ & 4.2432 & 0.95468 & 1 \\
\hline 2. & $\begin{array}{l}\text { Planning and Design Stage- Better understanding } \\
\text { via model visualization in 3D }\end{array}$ & 4.2432 & 0.89460 & 2 \\
\hline 3. & $\begin{array}{l}\text { Facility Management Stage- Allow for future } \\
\text { updates of current asset information }\end{array}$ & 4.1351 & 0.85512 & 3 \\
\hline 4. & $\begin{array}{l}\text { Facility Management Stage- Provide a single source } \\
\text { of information for project handover }\end{array}$ & 4.1081 & 0.96563 & 4 \\
\hline 5. & $\begin{array}{l}\text { Construction Stage- Reduce construction errors and } \\
\text { waste }\end{array}$ & 4.1081 & 01.10010 & 5 \\
\hline 6. & $\begin{array}{l}\text { Construction Stage- Produce accurate quantity and } \\
\text { cost estimate }\end{array}$ & 4.0541 & 0.94122 & 6 \\
\hline 7. & $\begin{array}{l}\text { Planning and Design Stage- Improved efficiency for } \\
\text { design production }\end{array}$ & 4.0541 & 0.97028 & 7 \\
\hline 8. & $\begin{array}{l}\text { Planning and Design Stage-Quicker approvals of } \\
\text { project at early stages }\end{array}$ & 4.0541 & 0.99850 & 8 \\
\hline 9. & $\begin{array}{l}\text { Construction Stage- Improved communication } \\
\text { between all stakeholders }\end{array}$ & 4.0541 & 1.02594 & 9 \\
\hline 10. & $\begin{array}{l}\text { Facility Management Stage- Better information for } \\
\text { the whole lifecycle of asset management }\end{array}$ & 4.0270 & 1.04047 & 10 \\
\hline 11. & $\begin{array}{l}\text { Planning and Design Stage- Intelligent transfer of } \\
\text { information between stakeholders }\end{array}$ & 4.0000 & 1.10554 & 11 \\
\hline 12. & $\begin{array}{l}\text { Facility Management Stage- Enhanced evaluation } \\
\text { on maintenance approach of plant }\end{array}$ & 3.9730 & 0.89711 & 12 \\
\hline 13. & $\begin{array}{l}\text { Construction Stage- Effective and accurate project } \\
\text { time planning and sequencing }\end{array}$ & 3.9730 & 1.21304 & 13 \\
\hline 14. & $\begin{array}{l}\text { Planning and Design Stage- Upfront involvement of } \\
\text { key stakeholders for earlier feedback }\end{array}$ & 3.9730 & 0.98563 & 14 \\
\hline 15. & $\begin{array}{l}\text { Construction Stage- Improved safety, quality and } \\
\text { risk identification }\end{array}$ & 3.8378 & 1.01416 & 15 \\
\hline
\end{tabular}

Table 8: Critical success factors for BIM implementation (overall)

\begin{tabular}{clccc}
\hline No & \multicolumn{1}{c}{ Critical Success Factors for BIM Implementation } & AI & $\begin{array}{c}\text { Standard } \\
\text { Deviation }\end{array}$ & Rank \\
\hline 1 & Management- High commitment and continuous support & 4.2703 & 0.87078 & 1 \\
2 & Technology- Relevant software available for BIM application & 4.2162 & 0.88616 & 2 \\
3 & $\begin{array}{l}\text { Technology- Central repository system to house project } \\
\text { information }\end{array}$ & 4.1892 & 0.84452 & 3 \\
4 & & & \\
5 & Process- Comprehensive client's requirements & 4.1892 & 0.87679 & 4 \\
6 & People- Change of mindset and awareness & 4.1892 & 0.87679 & 5 \\
7 & People- Adequate education and trainings & 4.1622 & 0.89795 & 6 \\
8 & Management- Clear business plan, vision and mission & 4.1622 & 0.86646 & 7 \\
9 & Technology- Stable and fast internet network system & 4.1351 & 0.94757 & 8 \\
10 & Process- Systematic approach throughout project & 4.1351 & 0.91779 & 9 \\
11 & People- Well defined roles and responsibilities & 4.0811 & 0.95389 & 10 \\
12 & Technology- Other tools and equipment i.e. drone for reality & 4.0811 & 0.89376 & 11 \\
& modeling & 4.0000 & 0.97183 & 12 \\
13 & Process- Agreed deliverables for asset lifecycle & 4.0000 & 0.91287 & 13 \\
\hline
\end{tabular}


The result shown in Fig. 1 was employed to focus on the top portion of the critical success factors for BIM implementation throughout the lifecycle of power plant projects in Malaysia. From the Pareto chart, 8 out of 13 factors of BIM implementation were selected to be included in the concept map and "Management - High commitment and continuous support" stated the highest percentage among the critical factor with $7.9 \%$ followed by "Technology- Relevant software available for BIM application" (7.9\%), "-TechnologyCentral repository system to house project information" (7.8\%), "Process- Comprehensive client's requirements" (7.8\%), "People- Change of mindset and awareness" (7.7\%), "People- Adequate education and trainings" (7.7\%), "Management- Clear business plan, vision and mission" (7.6\%), and "Technology- Stable and fast internet network system" that indicated $7.6 \%$.

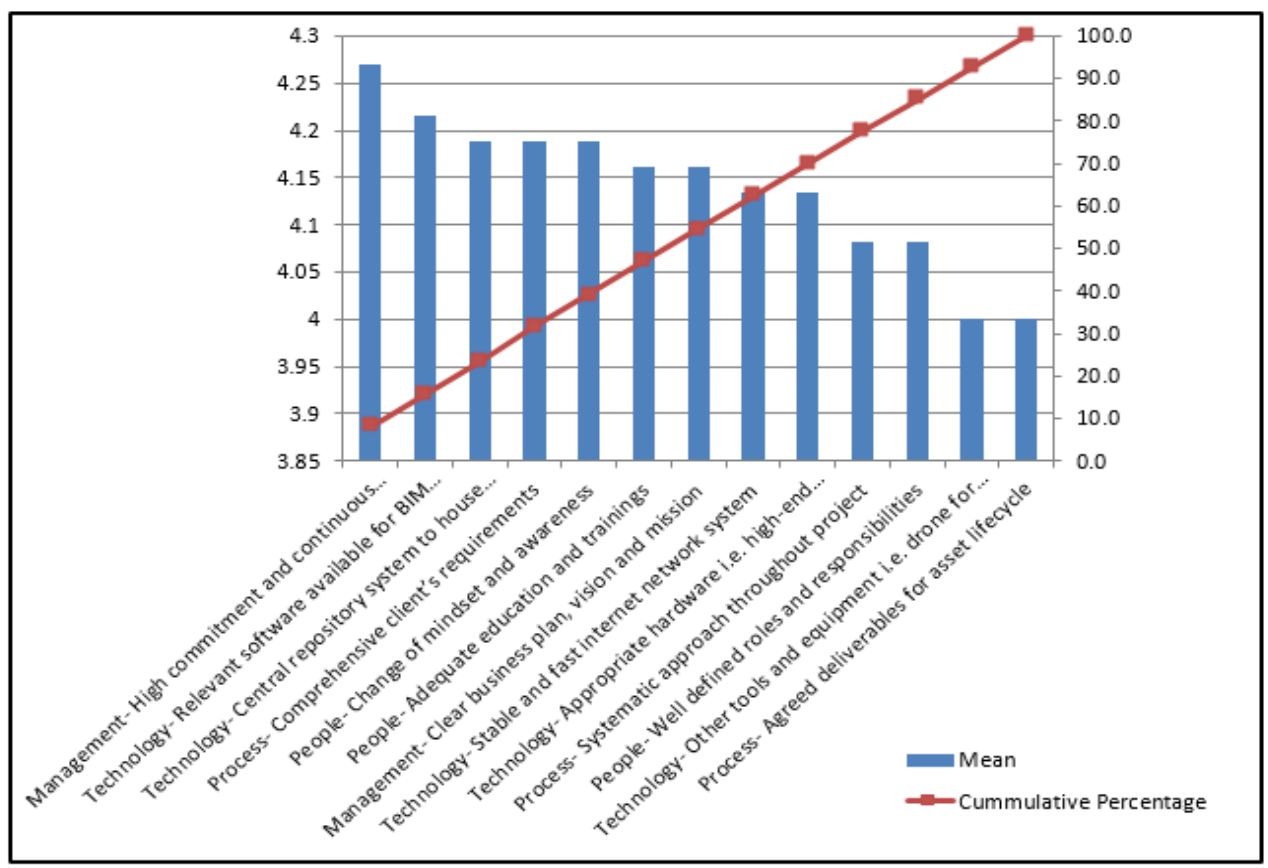

Fig. 1: Pareto analysis of critical success factors for BIM implementation throughout the lifecycle of power plant projects in Malaysia.

\section{CONCLUSION}

This research has identified the benefits of Building Information Modelling (BIM) to power plant projects' clients throughout the project lifecycle and has identified 13 critical success factors that need to be considered for BIM implementation in Malaysia. This research has identified the most important benefit of BIM for power plant projects is the improved coordination between client, consultant and contractor during the construction stage. Other benefits identified include better 3D visualisation during planning and design stage as well as smooth updates of asset information and single source handover project information during the facilities management stage. This research has also identified the most critical success factor for BIM implementation of power plant projects in Malaysia as the commitment and continuous management support. Besides that, the power plants project stakeholders consider relevant software availability, central repository system, comprehensive client's requirements and the change of mindset as the critical success factors for BIM adoption for power plant projects in Malaysia. 


\section{REFERENCES}

[1] Ipsos (2017) Reference Document \& Financial Report: It's Time for Simplicity.

[2] Bank Negara Malaysia (2019) Outlook and Policy in 2019. Bank Negara Malaysia

[3] World Economic Forum (2016) Shaping the Future of Construction. A Breakthrough in Mindset and Technology.

[4] Raja, A. K., \& Srivastava, A. P. (2006). Power plant engineering. New Age International.

[5] Ellabban O, Haitham AR, Blaabjerg F. (2014) Renewable energy resources: Status, prospects, and their enabling technology. Renewable and Sustainable Energy Reviews, 39: 748-764. DOI: 10.1016/j.rser.2014.07.113

[6] BP (2019) BP Statistical Review of World Energy

[7] ABB (2017) Digitalization and power generation Evolve, adapt, and thrive during the Energy and Fourth Industrial Revolutions, ABB White Paper.

https://library.e.abb.com/public/5b1f31f8444f41a7922b200207e47177/Digitalization\%20and $\%$ 20power\%20generation_WP.pdf

[8] CIDB (2008) Malaysian construction industry outlook, presentation by Business Development, Sector of CIDB, in Master Builders Journal (3rd Quarter), 2008, 8-14.

[9] CIDB (2009) Construction Economic Indicators. Kuala Lumpur: Construction Industry Development Board of Malaysia

[10] Borrmann, A., König, M., Koch, C., \& Beetz, J. (2018). Building information modeling: Why? what? how? In Building information modeling (pp. 1-24). Springer, Cham.

[11] Haron NA, Raja Soh RPZA, Harun AN. (2017) Implementation of Building Information Modelling (BIM) in Malaysia: A review. Pertanika Journal of Science \& Technology, 25(3): 661-674.

[12] Energy Commission (2017) Energy Malaysia, Volume 12, Energy Commission, Malaysia.

[13] Energy Commission (2017) Performance and Statistical Information on Electricity Supply Industry in Malaysia, Energy Commission.

[14] Shamsudin MSN, Rahman MN, Wahid MA. (2016) Power Generation Sources in Malaysia: Status and Prospects for Sustainable Development. Journal of Advanced Review on Scientific Research, 25(1): 11-28.

[15] Royal Institution of Chartered Surveyors (2014) International BIM implementation guide. https://www.rics.org/globalassets/rics-website/media/upholding-professionalstandards/sector-standards/construction/international-bim-implementation-guide-1st-editionrics.pdf

[16] Gerber BB, Rice S. (2015) The Perceived Value of Building Information Modeling in the U.S. Building Industry. Journal of Information Technology in Construction, 15: 185-201.

[17] Boston Consulting Group (2016) Digital in Engineering and Construction. The Transformative Power of Building Information Modeling.

[18] Energy Commission (2018) Malaysia_Energy_Statistics_Handbook, Energy Commission, Malaysia. http://www.sciencedirect.com/science/article/pii/S1364032114005656

[19] Bentley (2019) BIM Projects in China Using Bentley's Open Applications Are Setting a Higher Bar in Manufacturing and Power Generation. Bentley Systems. https://www.bentley.com/en/about-us/news/2019/october/21/901-ai-bim-projects-china

[20] CIDB Malaysia (2017) Malaysia Building Information Modeling Report 2016.

[21] CIDB (2015) Construction Industry Transformation Programme 2016-2020: Driving Construction Excellence together. CIDB (ISBN: 978-967-5317-96-5)

[22] Arya, R., Antonisamy, B., \& Kumar, S. (2012). Sample size estimation in prevalence studies. The Indian Journal of Pediatrics, 79(11), 1482-1488. https://link.springer.com/article/10.1007/s12098-012-0763-3

[23] Roscoe JT. (1975) Fundamental Research Statistics for the Behavioral Sciences. (2nd Edition). New York: Holt, Rinehart, and Winston.

[24] Sekaran. (2003) Research methods for business (4th edition). New York, USA: John Wiley \& Sons, vol. 65. https://doi.org/10.1017/CBO9781107415324.004

[25] Millar M, Dillman DA. (2012) Encouraging Survey Response via Smartphones. Survey Practice 5(3). https://doi.org/10.29115/SP-2012-0018 
[26] Sekaran U, Bougie R. (2013) Research methods for business: a skill-building approach (6th ed.). Chichester, West Sussex: John Wiley \& Sons, Inc.

[27] Joppe, M. (2000). The research process. Retrieved February 2000.

https://www.academia.edu/930161/The_research_process?pop_sutd=true 